\title{
Knowledge, attitude, and practices (KAP) towards COVID-19 among Nepalese residents during the COVID-19 outbreak: An online cross-sectional study
}

Sachina Paudel ( $\square$ sachiii137@gmail.com )

Government of Nepal https://orcid.org/0000-0002-6020-4545

Prabin Shrestha

Department of Psychology, Tribhuvan University, Kathmandu, Nepal

Isha Karmacharya

Central Institute of Science and Technology, Kathmandu, Nepal

Om Krishna Pathak

Bharatpur Hospital, Government of Nepal

Research article

Keywords: Knowledge, Attitude, Practices, Nepalese residents, COVID-19

Posted Date: June 9th, 2020

DOI: https://doi.org/10.21203/rs.3.rs-31044/v1

License: (c) (i) This work is licensed under a Creative Commons Attribution 4.0 International License.

Read Full License 


\section{Abstract \\ Background.}

The objective of this study was to assess the knowledge, attitude and practices of COVID-19 among Nepalese population, as containment of the disease is only possible with the change in behaviours as preventive measures.

\section{Methodology.}

A web-based cross-sectional survey was conducted for a period of two month among Nepalese residents aged $\geq 18$ years using a previously validated tool. Unrestricted self-selected, convenient sampling method was adopted to generate a heterogeneous sample. Data were analysed in SPSS version 22 using chisquare/Fisher-exact test, independent t-test, multiple linear regression and binary logistic regression.

\section{Results.}

Out of 766 participants, $78.3 \%$ were aged $20-39$ years and $58.2 \%$ were residents of province 3 . One-third of the respondents were students followed by health workers. The rates for correct answer for COVID-19 knowledge questionnaire ranged from 30-99\% with health workers and participants with bachelor's degree having significantly better knowledge. Of the total participants, $71.5 \%$ agreed that COVID-19 will be effectively controlled and $80 \%$ were assured that Nepal could win the fight against COVID-19. The majority of the participants had not visited any crowded place (93.1\%) which was significantly associated with age, marital status, gender, education, occupation, province of residence, and knowledge score of COVID-19 and $92.4 \%$ participants wore masks while going out which significantly differed across gender.

\section{Conclusion.}

There is a need to provide education and awareness about COVID-19 to Nepalese people focusing on the areas of knowledge gap so that Nepal can have victory against COVID-19.

\section{Background}

In 2019, a newly discovered infectious disease known as a coronavirus (COVID-19) was first identified in Wuhan, China in December [1-3]. Due to erratic growth of COVID-19 across the globe, World Health Organization (WHO) confirmed it as a public health emergency of international concern (PHEIC) on 30 Jan 2020 [4]. After verifying the outbreak at perturbing levels of spread and severity, on March 11, WHO characterized COVID-19 as a pandemic $[1,5]$. The mortality and morbidity of COVID-19 is rapidly changing 
across the world; and as of May 18, there were over 4,618,821 reported positive cases with 311,847 deaths [6].

Coronaviruses are positive sense RNA viruses, having six different species, known to cause mild to severe respiratory disease to human [2]. The virus have capacity of human-human transmission through droplets, aerosol, contact etc. having incubation period of 14 days and even longer [1]. The challenges remains with no development of effective drugs and vaccines where WHO emphasizes on crucial preventive measures. Public health preventive actions such as hand washing, social distancing, travel restrictions, case detection, contract tracing, quarantine, have been taken through collaborative efforts from all countries $[7,8]$.

In Nepal, Ministry of Health and Population (MOHP) [9], officially confirmed the first case of COVID-19 on 23 January 2020, detected on a 31 years male who travelled back from Wuhan, China to the capital city (Kathmandu) of Nepal. After two month, second case was identified on 22 March 2020 [9]. As of 28th April 2020, 52 cases of COVID-19 have been reported with 16 recovered [9]. First COVID-19 death occurred in Nepal on 16 May 2020. As of 19th May, the number of positive cases was 402 with two mortality and 36 recovered cases [9]. Nepal had initiated several preventive measures such as strengthened the health desk in International and other airports, closing of Nepal-China border, strengthened health desk in NepalIndia border, establishment of temporary - delegates corona hospital in various parts of the country [10]. On 24 March, Government of Nepal announced a lockdown, which was extended for the seventh time until 2 June 2020 [11]. The consequences and impact of the lockdown have been felt throughout the country.

To achieve a victory against COVID-19 and end the lockdown period in Nepal, measurement of people's obligation towards preventive measures of COVID-19 is necessary. In addition, the containment of the disease is possible only with the change in behaviours as preventive measures. Therefore, for effective planning and implementation of preventive measures, it is crucial to examine the KAP of Nepalese population during COVID19 outbreak. Very few researches have conducted in Nepal for assessing KAP of Nepalese people. This study describes the KAP of Nepalese people during the COVID-19 outbreak in Nepal with delivering the valuable recommendations. In addition, it would provide appropriate strategies to policy maker to develop the effective intervention for controlling COVID19 and improving the situation in further outbreaks.

\section{Methods}

\section{Study design, participants and Data Collection}

A web-based cross-sectional survey was conducted between 1 March and 29 April 2020 for a period of two months. The morbidity from COVID-19 was one on 1 March while the number of cases reached to 57 at the end of April, affecting 14 districts in six provinces of Nepal with no cases reported in Karnali province [9]. The online survey was conducted to all Nepalese population age $\geq 18$ years and residing in 
any seven provinces of Nepal. Since the population was general people, only excluded was people $<18$ years of age. The online survey was preferred due to the pandemic situation and unable to conduct a community-based survey as well as the urgency of data collection considering the situation. Also, Management Information system (MIS) report from Nepal Telecom Authority (NTA) stated that the internet penetration rate was $72 \%$ (as 14 January 2020) [12] with literacy rate of $66 \%$ (CBS 2011 Report) in Nepal, adequate for conducting online survey [13].

Unrestricted self-selected, convenient sampling method was adopted to generate a heterogeneous sample [14]. The sample was 769 with 3 incomplete data, which have been excluded making the final sample of 766 .

Measurement of knowledge, attitude, and practices related to COVID-19, a previously validated tool was used. The tool was used to measure knowledge, attitude, and practice of COVID-19 among Chinese residents [15]. Permission was obtained to use the tool. The tool was adapted to fit the local context with some minor revisions with a few additional questions. After the finalization of the tools, the questionnaire for the survey was developed into a web-based system using an online Google form. The questionnaire was promoted through the authors' network using Facebook, WhatsApp, email and Linkedln for wider circulations to reach residents of all over Nepal. The online self-administered technique was adopted for data collection.

\section{Study instruments and Variables}

The online survey questionnaire consisted of two sections: the first part consisted of socio-demographic information while the second part consisted of information related to Knowledge, attitude, and practices related to COVID-19.

\section{Socio-Demographic Section}

The socio-demographic information included questions related to age, sex, education, occupation, and the province of current residence.

\section{COVID-19 related KAP}

The questions related to knowledge, attitude, and practices were divided into three different sections with a total of 16 questions. The questions about knowledge focused on clinical features of COVID-19, transmission, and prevention \& control with a total of 12 questions. The responses for knowledge parameters were true, false, and don't know. One score was given for the correct answer and zero for incorrect/don't know the answer. In this way, the total score for knowledge parameters ranged from 0-12, where higher scores indicated better knowledge. The measurement of attitude consisted of two questions related to the participant's consensus on control of the disease and the participant's self-assurance of the country in winning the fight against COVID-19. The practice parameter was measured using two questions related to going to crowded places and wearing a mask while going outside. In contrast to the 
validated tool, three additional questions related to practice were added related to washing hands after sneezing and coughing, frequently touching face, mouth, and nose with hands and covering mouth and nose with elbow or tissues while coughing and sneezing.

\section{Data analysis}

All the data received from the online system were checked for completeness. We received a total of 769 responses, however, 3 forms were incomplete and hence excluded from analysis, with a total of 766 responses for the final analysis. The data were managed in MS EXCEL v.2010 and analyzed in IBM SPSS version 22 software (SPSS Inc. Chicago IL, USA). Univariate analysis such as frequencies, percentage, mean and standard deviation of demographic variables and KAP were calculated. Furthermore, chisquare/Fisher- exact test, independent t-test, multiple linear regression and binary logistic regression tests were used to compare the knowledge, attitude, and practice behaviours with socio-demographic variables. Confidence intervals (Cls) of $95 \%$ were used to quantify the associations between sociodemographic variables and KAP. Knowledge score were standardized for carrying out analysis. For statistically significant for all statistical tests, two-tailed $p$-values $<0.05$ were considered.

\section{Ethical approval}

Ethical approval of the study was taken from the Institutional Review Committee at Bharatpur Hospital, Nepal on 1 March 2020. The initial page of the form contained background, objectives of the study, and consent, followed by the questionnaire only after voluntary agreement by the participants. Anonymity and confidentiality of the participants were maintained at all levels of the study.

\section{Results}

\section{Socio-demographic Characteristics}

A total of 766 participants completed the KAP online survey. Among these sample majority were from 2039 years of age with a mean of 31 years (standard deviation [SD]: 9.65, range: 18-70), 402 (52.5\%) were female, $352(46.0 \%)$ were married, the majority $(55.6 \%)$ held a bachelor's degree, the majority $(33.03 \%)$ were students, followed by (28.46\%) health worker, 446 (58.2\%) were residents from Province 3 (Table 1).

\section{Knowledge of Participants on COVID-19}

The knowledge score $(10.11 \pm 1.26$, range: $0-12)$ having an overall $84.25 \%(10.11 / 12 \star 100)$ of correct rate was significantly varied across education and occupation $(p<0.05)$ (Table 1$)$.

Among 12 knowledge questionnaire correct answer rates was 30-99\%. The clinical symptoms and isolation period was the queries with the highest true answers while eating or contacting wild animals was the question with the least correct answers. The least rate (30\%) was on a question related with the 
transmission, most of the participants (51\%) reported false and $18.6 \%$ reported not knowing the reason whether COVID-19 virus would transmitted through eating or contacting wild animals (Table 2).

We performed multiple regression analysis to investigate the relationship between demographic variables with knowledge scores. The analysis showed that knowledge score were significantly associated with occupation, education and practices at $95 \%$ confidence level. Health worker average knowledge level is higher than students, teachers and others by about $0.11(\beta$ : $-0.11, p<0.001)$, Education of higher secondary is lower than bachelor level by 0.025 (vs. bachelor, $\beta: 0.25, p<0.05$ ). One-unit increase in the standard deviation of the practice index is associated with a 0.091 standard deviation increase in the knowledge score index ( $\beta$ : 0.091, $p<0.05)$ while fixing other demographic variables (Table 3).

\section{Attitude towards COVID-19 and its Correlates}

The majority of the participants (71.5\%) agreed that COVID-19 will finally be successfully controlled and this attitude was significantly different across genders $(p=0.021)$ and residence province $(p=0.015)$. About $80 \%$ of the participants had confidence that Nepal can win the battle against COVID-19. However, none of the socio-demographic characteristics were found to be associated with the confidence of winning the battle against the disease (Table 4).

Multiple logistic regression analysis found that participants with a bachelor's degree (vs. higher secondary and below, OR: 1.77, 95\% Cl: 1.01-3.10, p<0.05) and other residence provinces (vs. Province 3 , OR: $0.66,95 \% \mathrm{Cl}: 0.47-0.92, \mathrm{p}<0.05)$ were significantly associated with disagreement/did not know the final success in controlling the disease. (Table 5).

\section{Practices towards COVID-19 and its Correlates}

Out of the total participants, the majority (93.1\%) had not visited any crowded place and (92.4\%) wore masks while going out recently. The practice of going to crowded place significantly differed across demographic characteristics (age $p=0.039$; gender $p=0.001$; marital status $p=0.014$; education $p<0.001$; occupation $p<0.001$; residence province $p<0.001)$ and COVID-19 knowledge score $(p=0.005)$ while the practice of wearing a mask while going outside significantly differed only across gender $(p=0.042)$ (Table 6).

Multiple logistic regression analysis showed that male participants (vs. female, OR: $2.43,95 \%$ Cl: 1.18 $5.01, p<0.05$ ) and participants residing in other provinces (vs. Province 3, OR: 2.46, 95\% Cl: 1.30-4.64, $p<0.01$ ) were more likely to go to crowded places, whereas those with higher education level [Bachelors (OR: $0.26,95 \% \mathrm{Cl}: 0.12-0.54, \mathrm{p}<0.001)$ and Masters and above (OR: $0.19,95 \% \mathrm{Cl}: 0.08-0.44, \mathrm{p}<0.001)$ ] and students (OR: $0.18,95 \% \mathrm{Cl}: 0.06-0.56, p<0.01)$ were less likely to go to crowded places. COVID-19 knowledge score (OR: $0.81,95 \% \mathrm{Cl}: 0.67-0.99, \mathrm{p}<0.05)$ was significantly associated with going to crowded places. There was a significant association among male participants (vs. female, OR: $1.88,95 \%$ Cl: $1.02-$ $3.49, p<0.05$ ) not wearing a mask while going outside (Table 7). 
The majority of the participants mentioned they wash their hands (85.7\%) after sneezing or coughing and cover their mouth and nose with their elbows or tissue (93.73\%) while sneezing and coughing and this practice was significantly different across occupation $(p=0.026)$. About $77.02 \%$ of the participants had rarely or sometimes touched their face, nose, and mouth, while about $23 \%$ had frequent face, nose, and mouth touching habit. Gender $(p<0.01)$ and education $(p<0.05)$ were found to be significantly associated with their practice of touching their face, nose, and mouth from their hand (Table 8).

\section{Discussion}

A similar online study of Nepal was found which assessed the KAP of COVID-19 on Nepalese residents [16]. The study comprised 760 participants and the range of correct answer for knowledge related questions were from 60 to $98.7 \%$ with the question on the risk of COVID-19 infection by eating or contacting domestic animals with least correct answers. Our study had 766 participants and the correct answer range for knowledge was between 30-99\% with the least correct answer on the same question. Regarding attitude, $78.4 \%$ of participants were confident that COVID-19 could be controlled successfully while this percentage was $71.5 \%$ in our study, and almost $80 \%$ (77.9\%) were convinced that Nepal could win the battle against COVID-19 which was similar (80\%) in our study. In terms of practice, $94.9 \%$ of participants recently had not been to crowded places and $88.2 \%$ were wearing masks correctly while for our study $93.1 \%$ had not been to crowded places and $92.4 \%$ wore masks while going outside [16].

The findings of our study were also similar to the previous study conducted in China [15].On knowledge questions, the study showed the range of correct answers between $70.2-98.6 \%$ with overall $90 \%$ correct answers which differed significantly between gender, age, marital status, education level, and place of residence. However, in our study, the overall correct answer was $84.25 \%$ with the lowest score on the question related to the risk of COVID-19 by eating or contacting wild animals. The possible reason for this could be that wild animal are not reared or eaten in Nepal. Knowledge scores significantly differed across education and occupation. The study in China showed that majority (90.8\%) of the respondents agreed that COVID-19 will be controlled successfully and this result was different across gender, education, occupation, and place of residence and $97.1 \%$ participants were confident that China can win the battle against COVID-19 which differed across marital status and education level. In our study, the results regarding attitude were found to be relatively lower. This difference could be because of lower knowledge of COVID-19 among Nepalese than the Chinese population. In terms of practice, the knowledge score was notably associated as $96.4 \%$ of participants in China had not visited crowded places and $98 \%$ of them wore masks while going out.

Our study shows a higher score in KAP on COVID-19 compared to a study conducted in Paraguay [17] and Malaysia [18]. The study in Paraguay showed an overall correct rate of $62 \%$ in knowledge test with significant differences in age, gender, education, marital status, and residence [17], while the study in 
Malaysia showed overall correct rate in the knowledge of $80.5 \%$ with higher scores among females, those above 50 years old, people residing in central Malaysia [18] and those with higher incomes, which was lower than our study (84.25\%). However, in the knowledge category, there were 13 questions related to knowledge. Likewise, only $66.28 \%$ agreed that COVID-19 will be successfully controlled which was significantly different across age, gender, education, marital status, occupation, residence, and knowledge on COVID-19 in Paraguay but our study showed a higher rate of $71.5 \%$, with a difference across gender and province of residence. The study in Malaysia, however, showed $83.1 \%$ agreed COVID-19 could be successfully controlled and $95.9 \%$ were confident that Malaysia could win the battle against COVID-19. The practice scores in the Paraguay study were lower than our study where $88.35 \%$ of participants recently had not visited any crowded place and $74.31 \%$ used masks while going outside. The scores were lower in Malaysia where $83.4 \%$ avoided crowded places and only $51.2 \%$ wore a mask when going outside.

Another study in Malaysia [19] to examine knowledge, perception and communication behaviour among publics in Malaysia showed that the level of knowledge, risk perceptions and positive communication behaviour related to COVID-19 was high, where the majority of the respondents correctly answered knowledge related questions, perceived the risks and impacts of COVID-19 seriously. Likewise, a similar study in Kenya in informal settlements [20] showed knowledge regarding COVID-19 symptoms and highrisk groups were accurate however some misconceptions remained regarding specific symptoms and considering children as high-risk groups. Another study conducted in Egypt to assess the knowledge, perceptions, and attitude of the public towards the disease showed that the participants had good knowledge and positive attitude towards the protective measures against COVID-19, which was mainly gained through social media and the internet. However, older and lower-income participants, less educated, and people of rural areas had lower knowledge about the disease [21]. Similarly, a study in Peru to assess the knowledge, attitudes, and vulnerability perception during coronavirus outbreak showed that Peruvians had adequate knowledge of COVID-19 and they correctly identified the symptoms and transmission of the disease. Knowledge of COVID-19 was strongly correlated with age, education, and occupation. The participants also had significant perceived susceptibility to the contracting virus, contracting a virus from others, and displaying stigmatized behaviour [22].

Furthermore, our study showed that participants from other provinces are more likely to go to crowded places, which can justify the increment of COVID-19 cases among people residing in provinces other than Province 3 in Nepal. All participants were literate with at least higher secondary education and the majority of them were students, teachers, or health workers (69\%) with less participation from other occupational groups. These characteristics could have led to high knowledge about the disease and less likely to go to crowded places. Some related information such as a source of information, stigma related to COVID-19, fears associated with it could not be assessed. Currently, Nepal is leading to exponential 
transmission and increment of COVID-19 cases [9], which requires further studies to reveal the factors behind this issue.

As of 13 May 2020, the total number of Polymerase Chain Reaction (PCR) tests was 21,340 and rapid tests were 60,319 . With these tests, Nepal identified a total of 219 COVID-19 positive cases of which 35 were recovered \& discharged and the remaining others were either in contact with health workers or in isolation and observation. A total of 184 cases were in isolation and 14,313 people were under quarantine [23]. Hence, there is a need to increase the number of tests and identify cases as early as possible and conduct systematic screening of contacts of the cases.

\section{Limitations}

Since the study is designed for web-based survey, this study would have several limitations, particularly the generalizability of the findings. Some participants may randomly select the responses to spend the least amount of time to respond to the questionnaire and it could not be generalized on people who don't use internet.

\section{Conclusions}

Our study identified that majority of the respondents had good knowledge, attitude, and practice towards COVID-19; however knowledge on some questions was poor. Overall, the level of KAP was found to be satisfactory though, it is lower compared to other countries. Hence, there is a need to provide education and awareness of COVID-19 to the people using the available means and different languages to different ethnic communities where COVID-19 cases supposed to be reaching peak. Also, people should be encouraged to stay at home, comply with the lockdown, wear mask correctly, and wash hands frequently or use hand sanitizers or alcohol rubs as available. National and the local bodies should give emphasis to public health measures with developing and adopting appropriate guideline. With combined and collective efforts, Nepal can win the battle against COVID-19.

\section{Abbreviations}

KAP: Knowledge, Attitude and Practice

WHO: World Health Organization

CDC: Centre for Disease Control and Prevention

MIS: Management Information system 
NTA: Nepal Telecom Authority

Cls: Confidence intervals

PCR: Polymerase Chain Reaction

\section{References}

1. Zhu H, Wei L, and Niu P. The novel coronavirus outbreak in Wuhan, China. Global Health Research Policy. 2020;5(1). https://doi.org/10.1186/s41256-020-00135-6

2. She $J$ Jiang, $J$ Ye, L. et al. Novel coronavirus of pneumonia in Wuhan, China: emerging attack and management strategies. Clinical Translational Medicine. 2020; 9(19). https://doi.org/10.1186/s40169-020-00271-z

3. Rights, Roles and Responsibilities of Health Workers; Including Key Considerations for Occupational Safety. Coronavirus Disease (COVID-19) Outbreak: World Health Organization; 2019. p.13.https://www.who.int/publications-detail/coronavirus-disease-(covid-19)-outbreak-rights-roles-andresponsibilities-of-health-workers-including-key-considerations-for-occupational-safety-and-health. Accessed in 3 March 2020.

4. 2019-nCoV outbreak is an emergency of international concern. WHO/Europe: International Health Regulation. Health Emergency. 2020; Available from http://www.euro.who.int/en/healthtopics/health-emergencies/international-health-regulations/news/news/2020/2/2019-ncovoutbreak-is-an-emergency-of-international-concern.Accessed in 3 March 2020.

5. Director-General's opening remarks at the media briefing on COVID-19. World Health Organization. WHO Dir. Gen. speeches. 2020; Available from https://www.who.int/dg/speeches/detail/whodirector-general-s-opening-remarks-at-the-media-briefing-on-covid-19--20-april-2020. Accessed 29 March 2020.

6. World Health Organization (WHO) Coronavirus disease 2019 (COVID19) Situation Report-119. Geneva, Switzerland. 2020; AAvailable from: https://www.who.int/docs/defaultsource/coronaviruse/situation-reports/20200518-covid-19-sitrep-119.pdf?sfvrsn=4bd9de25_4. Accessed 19 March 2020.

7. Recommendations for international traffic in relation to COVID-19 outbreak. In : WHO, COVID-19 Travel Advice. Available from: https://www.who.int/news-room/articles-detail/updated-whorecommendations-for-international-traffic-in-relation-to-COVID-19-outbreak. Accessed 29 March 2020.

8. Advice for public. WHO: Corona Virus Disease. World Health Organization. 2020. Retrieved from https://www.who.int/emergencies/diseases/novel-coronavirus-2019/advice-for-public. Accessed 29 March 2020.

9. Update on Covid-19 in Nepal. Ministry of Health and Population: MOHP Nepal COVID-19 Update. 2020. Retrieved from, https://covid19.mohp.gov.np/\#/. Accessed 18 May 2020. 
10. Health sector emergency response Plan. Ministry of Health and Population. Government of Nepal. 2020, Retrieved from https://www.who.int/docs/default-source/nepal-documents/novelcoronavirus/health-sector-emergency-response-plan-covid-19-endorsed-may-2020.pdf? sfvrsn=ef831f44_2. Accessed 19 May 2020.

11. Kathmandu Post. After second Covid-19 death, government extends lockdown to June 2. 2020. Retrieved from: https://kathmandupost.com/national/2020/05/17/government-extends-nationwidelockdown-until-june-2. Accessed 18 May 2020.

12. Nepal Telecommunications Authority MIS Report: 2076. 2020. 182:134.

13. Ministry of Education. Government of Nepal. In: Education in Figures 2017. Ministry of Education, Science \& Technology, Planning and Monitoring. Division, Statistics, Policy and Research Section, Singhdurbar, Kathmandu; 2017.

14. Fielding N, Lee R, and Blank G. The SAGE Handbook of Online Research Methods. In: Online Research Methods; 2012; p. 161-76.

15. Zhong BL, Luo W, Li H-M Zhang, Q-Q Liu, X-G Li, W-T, \& Li Y. Knowledge, attitudes, and practices towards COVID-19 among Chinese residents during the rapid rise period of the COVID-19 outbreak: a quick online cross-sectional survey. International Journal of Biological Science. 2020; 16(10): 174552. doi: $10.7150 /$ ijbs. 45221 .

16. Hussain A Garima, T Singh, B Ram, R \& Tripti R. Knowledge, attitudes, and practices towards COVID19 among Nepalese Residents: A quick online cross-sectional survey. Asian Journal of Medical Sciences. 2020; 11(3) 6-11, doi: 10.3126/ajms.v11i3.28485.

17. Carlos Miguel, Rios González. Knowledge, attitudes and practices towards COVID-19 in Paraguayans during outbreaks: a quick online survey. 2020; https://doi.org/10.1590/SciELOPreprints.149.

18. Azlan AA, Hamzah MR, Sern TJ, Ayub SH, Mohamad E. Public knowledge, attitudes and practices towards COVID-19: A cross-sectional study in Malaysia. PLoS ONE. 2020; 15(5). https://doi.org/10.1371/journal.pone.0233668

19. Mohd Hanafiah, Khayriyyah, and Chang Da Wan. Public knowledge, perception and communication behavior surrounding COVID-19 in Malaysia. Research Gate. 2020; DOI:

31124/advance.12102816.v1

20. Austrian K, Pinchoff J, Tidwell J B, White C, Abuya T, Kangwana B et al. COVID-19 related knowledge, attitudes, practices and needs of households in informal settlements in Nairobi, Kenya, Bulletin World Health Organization. 2020; doi: 10.2471/BLT.20.260281

21. Abdelhafiz A S, Mohammed Z, Ibrahim M E. et al. Knowledge, Perceptions, and Attitude of Egyptians towards the Novel Coronavirus Disease (COVID-19). Journal of Community Health. 2020;1(10). https://doi.org/10.1007/s10900-020-00827-7

22. Zegarra Valdivia, J A Chino, Vilca B N, \& Ames Guerrero R. Knowledge, perception and attitudes in Regard to COVID-19 Pandemic in Peruvian Population. Research gate. 2020; doi: 31234/osf.io/kr9ya

23. Update on Covid-19 in Nepal. Ministry of Health and Population: MOHP Nepal COVID 19 Update. 2020. Situation Report \#94 Health sector response to COVID-19. 2020; Available in 
https://drive.google.com/drive/folders/1woAxbWgkgEACBzaJs5YOLmEHusA1LMDs, Accessed in15 May 2020.

\section{Declarations}

\section{Acknowledgments}

We would like to acknowledge Dr. Yi Li, MD, Ph.D., \& his team at Wuhan Mental Health Center, China to authorizing to adopt the tool for our research in Nepal. We would also like to acknowledge all the participants who provide their time for the completion of the questionnaire without which the research would not have been possible.

\section{Author' Information}

Master's in Public Health, James P. Grant School of Public Health; Urban Health Promotion centre, Bharatpur Metropolitan City, Government of Nepal, Phone no +977-9845358800, email: sachiii137@gmail.com ; ORCID ID: https://orcid.org/0000-0002-6020-4545

Sachina Paudel

Lecturer, Tribhuvan University, Trichandra Multiple Campus, Department of Psychology, Ghantaghar, Kathmandu, Nepal

Prabin Shrestha

Lecturer, Central Institute of Science and Technology, New Baneshwor, Kathmandu, Nepal Isha Karmacharya

MD Pediatrics, Fellowship in Neonatology and Pediatric Critical Care, Bharatpur hospital, Government of Nepal

Om Krishna Pathak

\section{Authors' Contribution}

SP is responsible for conceptualization and methodology. SP, OKP, PS, and IK contributed to data collection, formal analysis, writing and critical review of the manuscripts. The final version was read and approved by all authors.

Corresponding author

Correspondence to Sachina Paudel.

4. Data Availability 
The data used to support the findings of this study are available from the corresponding author upon request.

\section{Funding Statement}

This research received no specific grant from any funding agency in the public, commercial, or not-forprofit sectors.

6. Ethics Declarations

Ethics approval and consent to participants

The KAP study was approved by the Bharatpur Hospital Institutional Review Board. A written informed consent was obtained from all participants via online survey form.

7. Consent for publication

Not applicable.

8. Competing interests

The authors declare to have no competing interests.

\section{Tables}

Table 1: Demographic characteristics and knowledge score of COVID-19 by demographic variables 


\begin{tabular}{|c|c|c|c|c|c|}
\hline Variables & & Total n (\%) & Knowledge score (mean \pm Standard deviation) & $t / F$ & p-value \\
\hline \multirow[t]{3}{*}{ Age } & $<20$ years & $67(8.8)$ & $0.20 \pm 1.2$ & 1.92 & 0.147 \\
\hline & $20-39$ years & $600(78.3)$ & $0.03 \pm 0.99$ & & \\
\hline & $\geq 40$ years & $99(12.9)$ & $0.06 \pm 0.88$ & & \\
\hline \multirow[t]{2}{*}{ Gender } & Male & $364(47.5)$ & $0.02 \pm 1.07$ & 0.433 & 0.66 \\
\hline & Female & $402(52.5)$ & $0.01 \pm 0.92$ & & \\
\hline \multirow[t]{2}{*}{ Marital Status } & With Spouse & $352(46.0)$ & $0.01 \pm 1.068$ & 0.27 & 0.39 \\
\hline & Without Spouse & $414(54.0)$ & $0.01 \pm 0.93$ & & \\
\hline \multirow[t]{3}{*}{ Education } & Higher Secondary & $95(12.4)$ & $0.28 \pm 1.09$ & 4.48 & $0.01 *$ \\
\hline & Bachelor & $426(55.6)$ & $0.04 \pm 0.89$ & & \\
\hline & Masters and Above & $245(32.0)$ & $0.04 \pm 1.11$ & & \\
\hline \multirow[t]{4}{*}{ Occupation } & Health Workers & $218(28.5)$ & $0.22 \pm 0.91$ & 4.99 & \multirow{4}{*}{$<0.001^{\star \star}$} \\
\hline & Teacher & $57(7.4)$ & $0.16 \pm 1.20$ & & \\
\hline & Students & $253(33.0)$ & $0.07 \pm 0.91$ & & \\
\hline & Others & $238(31.1)$ & $0.12 \pm 1.08$ & & \\
\hline \multirow[t]{2}{*}{ Province } & Province 3 & $446(58.2)$ & $0.04 \pm 0.947$ & 1.34 & 0.08 \\
\hline & Other Province & $320(41.8)$ & $0.06 \pm 1.06$ & & \\
\hline
\end{tabular}

(1) all the values were standardized; Level of statistical significance shown using asterisks: ${ }^{k} p<0.05$; ${ }^{*} p<0.001$; Others provinces include province 1,2,4,5,6,7; Others in Occupation included; students, teacher, agriculture, businessman, homemaker

Table 2: Knowledge of participants on COVID-19 according to gender 
Correct

\section{Answer Rate}

(\%)

Male Female

$\mathrm{n} \quad \mathrm{=n}=402$

$364 \quad(52.5)$

(47.5)
K1. The main clinical symptoms of COVID-19 are fever, fatigue, dry cough, and shortness of breath.

K1. The main clinicalsymptoms of coviD-19 are fever, fatigue, dy cough, and shortness of breath.

K2. Unlike the common cold, stuffy nose, runny nose, and sneezing are less common in persons infected with the COVID-19 virus.

K3. There currently is no effective cure for COVID-19-2019, but early symptomatic and supportive treatment can help most patients recover from the infection.

K4. Not all persons with COVID-19-2019 will develop severe cases. Only those who are elderly, have chronic illnesses, and are obese are more likely to be severe cases.

K5. Eating or contacting wild animals would result in the infection by the COVID-19 virus.

30

$84^{\star}$

$69 \quad 265 \quad 261$

(72.8) (64.9)

$96 \quad 348 \quad 391$

(95.6) (97.3)

$322 \quad 325$

(88.4) (80.8)

K6. Persons with COVID-19-2019 cannot infect the virus to others when a fever is not present.

84* $297 \quad 349$

(81.6) (86.8)

K7. The COVID-19 virus spreads via respiratory droplets of infected individuals.

$97 \quad 355 \quad 391$

(97.5) (97.3)

K8. Ordinary residents can wear general medical masks to prevent the infection by the COVID-19 virus.

K9. It is not necessary for children and young adults to take measures to prevent the infection by the $91 *$ $309 \quad 386$ COVID-19 virus.

K10. To prevent the infection by COVID-19, individuals should avoid going to crowded places such as 98 356395 bus stations and avoid taking public transportations.

K11. Isolation and treatment of people who are infected with the COVID-19 virus are effective ways 
*Significance at 0.05 level.

Table 3: Multiple linear regression on factors associated with COVID-19 knowledge

\begin{tabular}{llclc}
\hline Variable & Coefficients & Std. Error & t \\
\hline Age - group (<20 Vs 20-40 Vs >40 Years) & 0.031 & 0.08 & 0.37 & 0.7 \\
Gender (Male Vs Female) & -0.109 & 0.07 & -1.38 & 0.2 \\
\hline Marital (Without Spouse Vs With Spouse) & 0.006 & 0.06 & 1.15 & 0.2 \\
\hline Education (Higher Secondary Vs Bachelor) & 0.25 & 0.11 & 2.22 & $0.02^{*}$ \\
\hline Occupation (Health worker Vs Student Vs Teacher Vs Others & -0.11 & 0.03 & -3.64 & $0.0 * \star *$ \\
\hline Province (3 Vs Others) & 0.09 & 0.07 & -0.97 & 0.3 \\
\hline Practice Score & 0.09 & 0.03 & 2.46 & $0.01 *$ \\
\hline
\end{tabular}

Note: (1) all the values were standardized; Level of statistical significance shown using asterisks: ${ }^{\star} p<0.05 ;{ }^{* *} p<0.01 ;{ }^{* \star} p<0.001 ; 0$ Others provinces include province 1,2,4,5,6,7; Others in Occupation included; students, teacher, agriculture, businessman, homemaker 


\begin{tabular}{|c|c|c|c|c|c|c|c|c|}
\hline \multirow[t]{3}{*}{ Characteristics } & \multirow{3}{*}{$\begin{array}{l}\text { Total } \\
\text { n (\%) }\end{array}$} & \multicolumn{7}{|c|}{ Attitudes, $\mathrm{n}(\%)$ or mean (standard deviation) } \\
\hline & & \multicolumn{4}{|c|}{ A1: final success in controlling } & \multicolumn{3}{|l|}{$\begin{array}{l}\text { A2: the confidence of } \\
\text { winning }\end{array}$} \\
\hline & & Agree & Disagree & $\begin{array}{l}\text { Don't } \\
\text { know }\end{array}$ & $\begin{array}{l}\mathrm{p}- \\
\text { value }\end{array}$ & Yes & No & p-value \\
\hline Age-group (years) & & & & & 0.631 & & & 0.179 \\
\hline$<20$ & $67(8.8)$ & $\begin{array}{l}48 \\
(71.6)\end{array}$ & 7 (10.5) & $\begin{array}{l}12 \\
(17.9)\end{array}$ & & 56 (83.6) & $\begin{array}{l}11 \\
(16.4)\end{array}$ & \\
\hline $20-39$ & $\begin{array}{l}600 \\
(78.3)\end{array}$ & $\begin{array}{l}434 \\
(72.3)\end{array}$ & $\begin{array}{l}73 \\
(12.2)\end{array}$ & $\begin{array}{l}93 \\
(15.5)\end{array}$ & & 487 (81.2) & $\begin{array}{l}113 \\
(18.8)\end{array}$ & \\
\hline 40 & 99 (12.9) & $\begin{array}{l}66 \\
(66.7)\end{array}$ & $\begin{array}{l}17 \\
(17.2)\end{array}$ & $\begin{array}{l}16 \\
(16.2)\end{array}$ & & $73(73.7)$ & $\begin{array}{l}26 \\
(26.3)\end{array}$ & \\
\hline Gender & & & & & $0.021 *$ & & & 0.297 \\
\hline Male & $\begin{array}{l}364 \\
(47.5)\end{array}$ & $\begin{array}{l}263 \\
(72.3)\end{array}$ & $55(15.1)$ & $46(12.6)$ & & $287(78.8)$ & $77(21.2)$ & \\
\hline Female & $\begin{array}{l}402 \\
(52.5)\end{array}$ & $\begin{array}{l}285 \\
(70.9)\end{array}$ & $42(10.4)$ & $75(18.7)$ & & $329(81.8)$ & $73(18.2)$ & \\
\hline Marital Status & & & & & 0.846 & & & 0.267 \\
\hline With Spouse & $\begin{array}{l}352 \\
(46.0)\end{array}$ & $\begin{array}{l}251 \\
(71.3)\end{array}$ & $47(13.4)$ & $54(15.3)$ & & 277 (78.7) & $\begin{array}{l}75 \\
(21.3)\end{array}$ & \\
\hline Without Spouse & $\begin{array}{l}414 \\
(54.0)\end{array}$ & $\begin{array}{l}297 \\
(71.7)\end{array}$ & $50(12.1)$ & $67(16.2)$ & & 339 (81.9) & $\begin{array}{l}75 \\
(18.1)\end{array}$ & \\
\hline Education & & & & & 0.150 & & & 0.923 \\
\hline $\begin{array}{l}\text { Higher Secondary and } \\
\text { Below }\end{array}$ & d 95 (12.4) & $\begin{array}{l}75 \\
(78.9)\end{array}$ & $7(7.4)$ & $\begin{array}{l}13 \\
(13.7)\end{array}$ & & 75 (78.9) & $\begin{array}{l}20 \\
(21.1)\end{array}$ & \\
\hline Bachelors & $\begin{array}{l}426 \\
(55.6)\end{array}$ & $\begin{array}{l}291 \\
(68.3)\end{array}$ & $\begin{array}{l}59 \\
(13.9)\end{array}$ & $\begin{array}{l}76 \\
(17.8)\end{array}$ & & 344 (80.8) & $\begin{array}{l}82 \\
(19.2)\end{array}$ & \\
\hline Masters and above & $\begin{array}{l}245 \\
(32.0)\end{array}$ & $\begin{array}{l}182 \\
(74.3)\end{array}$ & $\begin{array}{l}31 \\
(12.6)\end{array}$ & $\begin{array}{l}32 \\
(13.1)\end{array}$ & & 197 (80.4) & $\begin{array}{l}48 \\
(19.6)\end{array}$ & \\
\hline
\end{tabular}




\begin{tabular}{|c|c|c|c|c|c|c|c|c|}
\hline Occupation & & & & & 0.768 & & & 0.272 \\
\hline Health Workers & $\begin{array}{l}218 \\
(28.5)\end{array}$ & $\begin{array}{l}159 \\
(72.9)\end{array}$ & $29(13.3)$ & $30(13.8)$ & & $179(82.1)$ & $\begin{array}{l}39 \\
(17.9)\end{array}$ & \\
\hline Teachers & $57(7.4)$ & 38 (66.7) & $9(15.8)$ & $10(17.5)$ & & 45 (78.9) & $\begin{array}{l}12 \\
(21.1)\end{array}$ & \\
\hline Students & $\begin{array}{l}253 \\
(33.0)\end{array}$ & $\begin{array}{l}183 \\
(72.3)\end{array}$ & $26(10.3)$ & $44(17.4)$ & & $210(83.0)$ & $\begin{array}{l}43 \\
(17.0)\end{array}$ & \\
\hline Others \#\# & $\begin{array}{l}238 \\
(31.1)\end{array}$ & $\begin{array}{l}168 \\
(70.6)\end{array}$ & $33(13.9)$ & $37(15.5)$ & & $182(76.5)$ & $\begin{array}{l}56 \\
(23.5)\end{array}$ & \\
\hline $\begin{array}{l}\text { Province of current } \\
\text { residence }\end{array}$ & & & & & $0.015^{*}$ & & & 0.903 \\
\hline Province 3 & $\begin{array}{l}446 \\
(58.2)\end{array}$ & $\begin{array}{l}302 \\
(67.7)\end{array}$ & $\begin{array}{l}61 \\
(13.7)\end{array}$ & $\begin{array}{l}83 \\
(18.6)\end{array}$ & & $358(80.3)$ & $\begin{array}{l}88 \\
(19.7)\end{array}$ & \\
\hline Other Provinces\# & $\begin{array}{l}320 \\
(41.8)\end{array}$ & $\begin{array}{l}246 \\
(76.9)\end{array}$ & $\begin{array}{l}36 \\
(11.2)\end{array}$ & $\begin{array}{l}38 \\
(11.9)\end{array}$ & & $258(80.6)$ & $\begin{array}{l}62 \\
(19.4)\end{array}$ & \\
\hline $\begin{array}{l}\text { COVID-19 } \\
\text { knowledge score }\end{array}$ & $\begin{array}{l}\text { Score } \\
\text { range } \\
0-12\end{array}$ & $\begin{array}{l}10.1 \\
(1.2)\end{array}$ & $\begin{array}{l}10.2 \\
(1.2)\end{array}$ & $\begin{array}{l}10.0 \\
(1.4)\end{array}$ & 0.447 & $10.1(1.2)$ & $\begin{array}{l}10.0 \\
(1.5)\end{array}$ & 0.188 \\
\hline
\end{tabular}

\#other provinces are Province 1, 2, 4, 5, 6 and 7; \#\# others include Agriculture, Businessman, Home-makers; ${ }^{*}$ significance at $p<0.05$;

**significance at $p<0.01$; ap-value from Fisher's Exact Test

Table 5. Results of multiple binary logistic regression analysis on factors significantly associated with attitudes towards COVID-19

\begin{tabular}{lll}
\hline Variable & \multicolumn{2}{c}{$\begin{array}{c}\text { A1: final success in controlling } \\
\text { (Reference category is: Agree) }\end{array}$} \\
\hline Education (Higher Secondary and Below Vs Bachelor) & OR (95\% CI) & P Value \\
\hline Place of Residence (Province 3 Vs Other Provinces) & $0.66(1.01-3.10) *$ & $<0.05$ \\
\hline
\end{tabular}

All covariates were adjusted.

Page 18/24 
Table 6. Practices towards COVID-19 by demographic variables 


\begin{tabular}{|c|c|c|c|c|c|c|c|}
\hline \multirow[t]{3}{*}{ Characteristics } & \multirow{3}{*}{$\begin{array}{l}\text { Total } \\
\text { n (\%) }\end{array}$} & \multicolumn{6}{|c|}{$\begin{array}{llll}\text { Practices, } \mathrm{n} \text { (\%) } & \text { or mean } \\
\text { deviation) } & & & \\
\end{array}$} \\
\hline & & \multicolumn{3}{|c|}{ P1: going to a crowded place } & \multirow{2}{*}{\begin{tabular}{|l} 
P2: wearing \\
mask \\
Yes
\end{tabular}} & \multirow{2}{*}{$\begin{array}{l}\text { a } \\
\text { - } \\
\text { No }\end{array}$} & \multirow[b]{2}{*}{ p-value } \\
\hline & & Yes & No & p-value & & & \\
\hline Age-group (years) & & & & 0.039 & & & 0.616 \\
\hline$<20$ & $67(8.8)$ & $5(7.5)$ & $62(92.5)$ & & $60(89.6)$ & $7(10.4)$ & \\
\hline $20-39$ & $600(78.3)$ & $35(5.8)$ & $\begin{array}{l}565 \\
(94.2)\end{array}$ & & 557 (92.8) & $43(7.2)$ & \\
\hline 40 & 99 (12.9) & $\begin{array}{l}13 \\
(13.1)\end{array}$ & $86(86.9)$ & & 91 (91.9) & $8(8.1)$ & \\
\hline Gender & & & & $0.001^{* *}$ & & & $0.042^{*}$ \\
\hline Male & $364(47.5)$ & $\begin{array}{l}37 \\
(10.2)\end{array}$ & $\begin{array}{l}327 \\
(89.8)\end{array}$ & & 329 (90.4) & $35(9.6)$ & \\
\hline Female & $402(52.5)$ & $16(4.0)$ & $\begin{array}{l}386 \\
(96.0)\end{array}$ & & 379 (94.3) & $23(5.7)$ & \\
\hline Marital Status & & & & $0.014^{*}$ & & & 0.233 \\
\hline With Spouse & $352(46.0)$ & $33(9.4)$ & $\begin{array}{l}270 \\
(90.6)\end{array}$ & & 321 (91.2) & $31(8.8)$ & \\
\hline Without Spouse & $414(54.0)$ & $20(4.8)$ & $\begin{array}{l}394 \\
(95.2)\end{array}$ & & 387 (93.5) & $27(6.5)$ & \\
\hline Education & & & & $<0.001$ & & & 0.288 \\
\hline $\begin{array}{l}\text { Higher Secondary } \\
\text { Below }\end{array}$ & and 95 (12.4) & $\begin{array}{l}23 \\
(24.2)\end{array}$ & $72(75.8)$ & & $84(88.4)$ & $11(11.6)$ & \\
\hline Bachelors & $426(55.6)$ & $17(4.0)$ & $\begin{array}{l}409 \\
(96.0)\end{array}$ & & $396(93.0)$ & $30(7.0)$ & \\
\hline Masters and above & $245(32.0)$ & $13(5.3)$ & $\begin{array}{l}232 \\
(94.7)\end{array}$ & & $228(93.1)$ & $17(6.9)$ & \\
\hline Occupation & & & & $<0.001^{\mathrm{a}}$ & & & $0.733^{\mathrm{a}}$ \\
\hline
\end{tabular}




\begin{tabular}{|c|c|c|c|c|c|c|c|}
\hline Health Workers & $218(28.5)$ & $17(7.8)$ & 201 (92.2) & & 203 (93.1) & $15(6.9)$ & \\
\hline Teachers & $57(7.4)$ & $2(3.5)$ & $55(96.5)$ & & $53(93.0)$ & $4(7.0)$ & \\
\hline Students & $253(33.0)$ & $5(2.0)$ & $248(98.0)$ & & 236 (93.3) & $17(6.7)$ & \\
\hline Others \#\# & $238(31.1)$ & $29(12.2)$ & $209(87.8)$ & & 216 (90.8) & $22(9.2)$ & \\
\hline Province of current residence & & & & $<0.001$ & & & 0.624 \\
\hline Province 3 & $446(58.2)$ & $18(4.0)$ & $\begin{array}{l}428 \\
(96.0)\end{array}$ & & $414(92.8)$ & $32(7.2)$ & \\
\hline Other Provinces & $320(41.8)$ & $\begin{array}{l}35 \\
(10.9)\end{array}$ & $\begin{array}{l}285 \\
(89.1)\end{array}$ & & $294(91.9)$ & $26(8.1)$ & \\
\hline $\begin{array}{l}\text { COVID-19 } \\
\text { knowledge score }\end{array}$ & $\begin{array}{l}\text { Score } \\
\text { range } \\
0-12\end{array}$ & $9.6(1.7)$ & $10.1(1.2)$ & $0.005^{* *}$ & 10.1 (1.2) & $9.9(1.7)$ & 0.184 \\
\hline
\end{tabular}

\#other provinces are Province 1, 2, 4, 5, 6 and 7; \#\# others include Agriculture, Businessman, Home-makers; *significance at $p<0.05$;

**significance at $p<0.01$; ap-value from Fisher's Exact Test

Table 7. Results of multiple binary logistic regression analysis on factors significantly associated with practices towards COVID-19 


\begin{tabular}{|c|c|c|}
\hline \multirow[t]{4}{*}{ Variables } & $\begin{array}{l}\text { P1: going to a crowded } \\
\text { place }\end{array}$ & $\begin{array}{l}\text { P2: wearing a mask } \\
\text { Reference category is: }\end{array}$ \\
\hline & Reference category is: & Yes \\
\hline & Yes & \\
\hline & OR (95 \% CI) & OR (95 \% CI) \\
\hline Age-group (years; <20 Vs 20-39 Years) & $1.81(0.54-6.06)$ & $0.54(0.21-1.38)$ \\
\hline Age-group (years; <20 Vs 20- 40 Years) & $1.13(0.29-4.45)$ & $0.48(0.14-1.63)$ \\
\hline Gender (Male Vs Female) & $2.43(1.18-5.01) *$ & $0.53(0.29-0.98) *$ \\
\hline Marital Status (With Spouse Vs Without Spouse) & $1.03(0.50-2.13)$ & $0.64(0.31-1.30)$ \\
\hline Education (Higher Secondary and Below Vs Bachelors) & $3.93(1.84-8.37) * * *$ & $0.82(0.37-1.80)$ \\
\hline Education (Higher Secondary and Below Vs Masters & 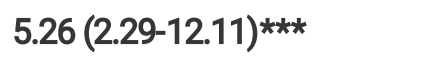 & $0.58(0.24-1.39)$ \\
\hline and above) & & \\
\hline Occupation (Health Workers Vs Students) & $5.58(1.80-17.26) * \star$ & $1.01(0.44-2.33)$ \\
\hline Province of current residence (Province 3 Vs Others) & $0.41(0.22-0.77) *$ & $1.07(0.61-1.86)$ \\
\hline COVID-19 & $1.23(1.01-1.50) *$ & $0.90(0.74-1.08)$ \\
\hline knowledge score & & \\
\hline
\end{tabular}

Significance at ${ }^{*} \mathrm{p}<0.05 ;{ }^{*} \mathrm{p}<0.01 ;{ }^{* \star} \mathrm{p}<0.001 ;$ All covariates were adjusted.

Table 8: Additional Practices towards COVID-19 by demographic variables 
P1: Do you wash your hands after sneezing or coughing? P-Value

\begin{tabular}{llll}
\hline Yes & No & May Be \\
$657(85.7)$ & $47(6.1)$ & $62(8.1)$ & \\
$28(7.9)$ & $20(5.7)$ & $54(15.3)$ & $0.016^{*}$ \\
$19(4.6)$ & $42(10.2)$ & $67(16.2)$
\end{tabular}

\begin{tabular}{llcccc} 
Marital & With Spouse & $28(7.9)$ & $20(5.7)$ & $54(15.3)$ & $\mathbf{0 . 0 1 6 *}$ \\
\cline { 2 - 4 } Status & Without Spouse & $19(4.6)$ & $42(10.2)$ & $67(16.2)$
\end{tabular}

P2: How Often you touch your face, nose, mouth from your hand

\begin{tabular}{|c|c|c|c|c|c|}
\hline & & Yes & No & May Be & \\
\hline & & $176(22.9 \%)$ & $366(47.7)$ & $224(29.2)$ & \\
\hline \multirow[t]{2}{*}{ Gender } & Male & $103(28.3)$ & $166(45.6)$ & $95(26.1)$ & $0.003^{*}$ \\
\hline & Female & $73(18.1)$ & $200(49.7)$ & $129(32)$ & \\
\hline \multirow[t]{3}{*}{ Education } & Higher Secondary and Below & $28(29.5)$ & $30(31.6)$ & $37(38.9)$ & $0.012^{*}$ \\
\hline & Bachelors & 89 (20.8) & $218(51.17)$ & $119(27.9)$ & \\
\hline & Masters and above & $59(24.1)$ & $118(48.16)$ & 68 (27.7) & \\
\hline
\end{tabular}

P3: Do you cover your mouth and nose with an elbow or tissue while sneezing or coughing.

\begin{tabular}{|c|c|c|c|c|c|}
\hline & & Yes & No & May be & \\
\hline & & 176 (22.9\%) & $366(47.78)$ & 224 (29.24) & \\
\hline \multirow[t]{3}{*}{ Occupation } & Health Workers & $212(97.2)$ & $3(1.3)$ & $3(1.4)$ & $0.026^{*}$ \\
\hline & Teachers & $55(96.5)$ & $2(3.5)$ & 0 & \\
\hline & Students & $228(90.1)$ & $8(3.1)$ & $17(6.7)$ & \\
\hline
\end{tabular}

${ }^{*}$ significance at $\mathrm{p}<0.05$; **significance at $\mathrm{p}<0.01$; ap-value from Fisher's Exact Test

\section{Supplementary Files}

This is a list of supplementary files associated with this preprint. Click to download. 
- supplement1.docx

Page 24/24 